\title{
PREVALENCE OF DEPRESSION, ANXIETY AND INSOMNIA IN CHRONIC KIDNEY DISEASE PATIENTS AND THEIR CO-RELATION WITH THE DEMOGRAPHIC VARIABLES
}

\author{
H.K. Aggarwal, Deepak Jain, Geeta Dabas, R K Yadav
}

Department of Medicine and Division of Nephrology

Pt. B.D. Sharma University of Health Sciences, ROHTAK-124001 (Haryana) INDIA.

Corresponding author: Dr. Deepak Jain, Department of Medicine, Pt. B.D. Sharma University of Health Sciences, Rohtak-124001 (Haryana), India. E-mail:jaindeepakdr@gmail.com Ph: +91-9416147887

\section{ABSTRACT}

Background: Chronic kidney disease (CKD) is an emerging health problem in both developed and developing countries. Depression, anxiety and sleep disturbances are highly prevalent in patients with chronic disease, but remain undertreated despite significant negative consequences on patients' health. Assessment of key components of mental health early in disease course will help to identify high risk subjects in whom modifying these predictors will help in providing active and healthy life in CKD patients.

Methods: We did a cross sectional study in 200 patients of CKD stage III to V-D fulfilling the eligibility criteria who were on follow up in a single tertiary care center in the state of Haryana, India. We assessed the prevalence of anxiety, depression and insomnia and their correlation with demographic variables in these patients. The structured questionnaire used in this study gathered information on respondent demographic and disease characteristics, and information obtained from the HADS and PSQI questionnaire. Factors associated with anxiety, depression and insomnia were examined by a multiple logistic regression analysis.

Results: The prevalence of anxiety, depression and insomnia were found to be $71 \%, 69 \%$ and $86.5 \%$ respectively. As the CKD stage advanced, the prevalence as well as severity of these parameters increased. Anxiety, depression and sleep quality were found to be significantly correlated to unemployment, low income, low education, urban residence and presence of co-morbidities. The anxiety, depression and insomnia scores were found to have a strong negative correlation with eGFR, hemoglobin, serum calcium $(\mathrm{p}<0.01)$ and a positive correlation with TLC, blood urea, serum creatinine and serum phosphate $(\mathrm{p}<0.05)$.

Conclusion: We observed a high prevalence of anxiety, depression and insomnia in CKD patients. There is a need to develop strategies to accurately identify "high risk" subjects who may benefit from preventive measures before complications occur. By identifying CKD patients with high risk of developing these mental health related issues, healthcare provider may be better able to ensure the provision of appropriate rehabilitation to this population.

Key words: Chronic kidney disease, depression, anxiety, insomnia.

\section{INTRODUCTION}

Chronic kidney disease (CKD) is a major health concern and like many chronic illnesses is invariably associated with various psychiatric conditions and poorer quality of life. CKD negatively affects patients' social, financial, and psychological well-being. [1,2] Patients with CKD are thought to be highly susceptible to emotional problems because of the chronic stress related 
to disease burden, dietary restrictions, functional limitations, associated chronic illness, adverse effects of medication, changes in self-perception and fear of death. Hemodialysis patients have lower quality of life, more functional impairments, greater occurrence of psychopathological states including suicide, lower adherence to drug treatment and an increased likelihood of long term body-pain.[3] Therefore, the diagnosis and treatment of these conditions becomes important to improve psychological and overall well-being, quality of life and consequently, reduce morbidity and mortality risk in this population.

Overall, depression is the most common psychiatric/psychological problem (likely together with anxiety). The estimated prevalence of depressive disorders is $13-22 \%$ in primary care clinics but is only recognized in approximately $50 \%$ of cases. [4] Since many symptoms of depression overlap with those present in CKD due to uremia, many patients remain undiagnosed by the treating physician. Anxiety in CKD patients often co-occur with depression and even seem to aggravate the depressive symptoms and impaired quality of life. Both depression and anxiety are predictors of morbidity and mortality in dialysis patients, and are responsible for compromising treatment compliance and downgrading their immune and nutritional status. Decreased quality of sleep is common in dialysis patients and is associated with decreased health-related quality of life.[5] The causes of poor sleep in CKD patients include anxiety, depression, fatigue, restless leg syndrome, obstructive sleep apnea etc. The reported prevalence of 'poor sleep' in dialysis patients is in the range of 45-80\%.[6]

Although some studies on depression, anxiety and sleep quality have been conducted, the majority of the studies conducted are from the western countries. Research findings on these mental health related issues in Indian CKD population is scarce. This study was aimed to examine the prevalence of anxiety, depression and insomnia in CKD population in India and their correlation with socio-demographic variables with a hope that findings may suggest appropriate psychological intervention strategies for Indian CKD patients.

\section{MATERIAL AND METHODS}

In this cross sectional study 200 patients of chronic kidney disease of stage III to V-D were recruited between May 2014 and October 2015 in Pt. B. D. Sharma PGIMS, Rohtak; a tertiary health care center in the state of Haryana, India. Patients aged $<18$ years, patients with pre-existing psy- chiatric illness or cognitive dysfunction, patients with transplanted kidney or any condition which precludes the patient from participating in study like drug abuse, pregnant females, malignancy were excluded from the study.

After due consideration into inclusion and exclusion criteria, and taking written informed consent patients were recruited. Operational definition of anxiety, depression and insomnia were taken as:

Anxiety: A subjective sense of unease, dread or foreboding, can indicate a primary psychiatric condition, or can be a component of, or reaction to, a primary medical disease.

Depression: Major depressive disorder is defined by DSM-IV as having a loss of pleasure or interest for 2 weeks, accompanied by 5 or more psychological, somatic and behavioral symptoms.

Insomnia: Subjective sensation of short, unsatisfying sleep, despite the ability to sleep. It may be secondary either to trouble falling asleep and/or to night-time waking, which must be persistently present (i.e. three to four times a week for several weeks).

A detailed history was taken and clinical examination done. The subjects then underwent routine laboratory investigations including baseline radiographic and biochemical evaluation. The demographic profile of each patient was recorded as per pre-specified proforma along with HADS questionnaire for anxiety and depression and PSQI for insomnia. The HADS is a fourteen item scale that generates ordinal data. Seven of the items relate to anxiety and seven relate to depression. This is a useful tool for the detection of anxiety and depression in people with physical health problems. The responses were scored on a scale of 0-3, with 3 indicating higher symptom frequencies. Score for each subscale can range from 0-21 with scores categorized as 0-7 normal, 8-10 mild anxiety/depression, 11-14 moderate anxiety/depression and 15-21 severe anxiety/ depression. Scores for the entire scale (emotional distress) range from 0-42, with higher scores indicating more distress. Sleep quality was measured using Pittsburgh Sleep Quality Index. PSQI is a self-report questionnaire that assesses sleep quality over a 1-month time interval. [7] It differentiates "poor" from "good" sleep by measuring seven domains: subjective sleep quality, sleep latency, sleep duration, habitual sleep efficiency, and sleep disturbances, use of sleep medication, and daytime dysfunction over the last month. Each domain is given a particular score which is finally summated and the global score 
predicts the quality of sleep. A score of $\geq 5$ is indicative of poor sleep quality.

The study population was divided in four groups based on eGFR and further comparisons were made.

Group A consisted of 50 patients with eGFR between $30-59 \mathrm{ml} / \mathrm{min} / 1.73 \mathrm{~m}^{2}$ (CKD Stage III).

Group B consisted of 50 patients with eGFR between $15-29 \mathrm{ml} / \mathrm{min} / 1.73 \mathrm{~m}^{2}$ (CKD Stage IV).

Another 100 patients of eGFR $<15 \mathrm{ml} /$ $\mathrm{min} / 1.73 \mathrm{~m}^{2}$ (stage $\mathrm{V}$ ) were recruited and divided into two groups on the basis of dialysis:

Group C consisted of 50 patients not on hemodialysis (CKD stage $\mathrm{V}$ ).

Group D consisted of 50 patients on hemodialysis for last 6 months (CKD stage-V D).

\section{Statistical Methods:}

IBM SPSS statistics software version 20 was used for the statistical analyses. Raw scores from the questionnaires were transformed to scale scores using the software syntax for HADS and PSQI. Data was analyzed and presented according to outcome of normal distribution tests. ANOVA test was used to analyze differences in quantitative variables between the groups. Independent t-test was used to compare mean anxiety, depression and PSQI scores related to categorized correlates. $P$ value of $<0.05$ was taken as significant.

\section{RESULTS:}

The study population consisted of $200 \mathrm{pa}-$ tients. The mean age was $50.11 \pm 13.99$ years, and most of the subjects were male $(64 \%)$, unemployed (57\%), married (94.5\%), belonging to low income group ( $\leq 1.5$ lac per annum) $(56 \%)$ and residing in rural area (52.5\%). Additionally, 58\% patients were educated up to elementary level while $34.5 \%$ patients had secondary education and only $7.5 \%$ were graduates. Nearly $50.5 \%$ patients had co-morbidity like cardiovascular disease, chronic airway disease, hypothyroidism, chronic liver disease, cerebrovascular disease. Among the etiological distribution most common cause of CKD was found to be diabetes mellitus (29\%) followed by chronic glomerulonephritis (26\%), hypertension (24.5\%) and obstructive uropathy $(9.5 \%)$. Less frequent etiologies included nephrotic syndrome and adult polycystic kidney disease.
As shown in Table 1 there was no statistically significant difference among four groups in values of age, SBP, DBP, MAP, blood sugar, serum uric acid, serum potassium. On the other hand hemoglobin, serum calcium and eGFR showed a statistically significant decline from group A to $\mathrm{D}$ while blood urea, serum creatinine and serum phosphate showed a rising trend from group A to D which was statistically significant $(p<0.05)$.

Out of 200 patients, 142 (71\%) patients had anxiety (HADS-A score $>7), 138$ (69\%) patients had depression (HADS-D score $>7$ ) and 173 $(86.5 \%)$ patients had poor sleep quality (PSQI score $\geq 5$ ). The mean anxiety, depression and insomnia scores were $11.16 \pm 3.91,10.74 \pm 3.69$ and $7.93 \pm 3.37$ respectively. The scores were higher than the threshold values, for diagnosis of these conditions, in most of the study population implying the presence of a high level of anxiety, depression and insomnia in patients of CKD. The mean anxiety, depression and insomnia scores showed a gradual increase from group A to D as shown in table 2 which was statistically significant $(p<0.001)$. These findings show that more advanced the stage of CKD, the more likely the patient is to have anxiety, depression and insomnia. Also the severity of disease increase as the CKD stage advances as shown by rising mean anxiety, depression and insomnia score from group A to D. (Table-2)

Table 3 displays the correlation of anxiety, depression and insomnia scores with various clinical and socio-demographic variables. The mean anxiety, depression and insomnia scores were found to be higher in those having $\mathrm{Hb}<9$, unemployed, those living in urban area and those having low income and associated co-morbidities $(\mathrm{p}<0.05)$.

Education level of patients was correlated with anxiety, depression and insomnia using independent t-test. Education level was not found to influence the levels of anxiety. However, mean depression and PSQI scores showed a significant decline from elementary to secondary level $(p<0.001)$ but the difference between secondary and university group was not significant ( $\mathrm{p}>0.05)$. These findings suggest that less educated patients reported significantly higher scores in depression and insomnia scales. (Table-4)

On applying Pearson correlation a statistically significant positive correlation of anxiety, depression and PSQI scores was found with total leukocyte count, blood urea, serum creatinine and serum phosphate and a statistically significant negative correlation was found with hemoglobin, serum calcium and eGFR. Depression and PSQI scores were also found 
Table 1: Baseline Demographic and Clinical Parameters of four groups

\begin{tabular}{|c|c|c|c|c|c|}
\hline Parameter & $\begin{array}{c}\text { Group A } \\
(n=50)\end{array}$ & $\begin{array}{c}\text { Group B } \\
(n=50)\end{array}$ & $\begin{array}{c}\text { Group C } \\
(n=50)\end{array}$ & $\begin{array}{c}\text { Group D } \\
(\mathrm{n}=\mathbf{5 0})\end{array}$ & p value ${ }^{* *}$ \\
\hline $\begin{array}{l}\text { Age (years) } \\
(\text { Mean } \pm S D)\end{array}$ & $49.52 \pm 13.34$ & $55.52 \pm 13.98$ & $51.78 \pm 13.83$ & $43.62 \pm 12.41$ & $>0.05$ \\
\hline \begin{tabular}{|l|}
$\mathrm{BMI}^{*}\left(\mathrm{~kg} / \mathrm{m}^{2}\right)$ \\
$(\mathrm{Mean} \pm \mathrm{SD})$
\end{tabular} & $23.33 \pm 5.41$ & $22.38 \pm 4.32$ & $21.53 \pm 3.23$ & $20.36 \pm 3.74$ & $<0.001$ \\
\hline \begin{tabular}{|l|}
$\begin{array}{l}\mathrm{SBP}^{*}(\mathrm{mmHg}) \\
(\mathrm{Mean} \pm \mathrm{SD})\end{array}$ \\
\end{tabular} & $137.24 \pm 18.81$ & $140.2 \pm 20.92$ & $134.32 \pm 20.19$ & $134.32 \pm 17.84$ & $>0.05$ \\
\hline \begin{tabular}{|l|}
$\begin{array}{l}\mathrm{DBP}^{*}(\mathrm{mmHg}) \\
(\text { Mean } \pm \mathrm{SD})\end{array}$ \\
\end{tabular} & $85.16 \pm 12.50$ & $85.84 \pm 10.16$ & $83.52 \pm 9.17$ & $83.48 \pm 9.39$ & $>0.05$ \\
\hline \begin{tabular}{|l}
$\operatorname{MAP}^{*}(\mathrm{mmHg})$ \\
$($ Mean \pm SD $)$
\end{tabular} & $102.52 \pm 13.35$ & $103.96 \pm 12.83$ & $100.42 \pm 12.18$ & $100.42 \pm 11.60$ & $>0.05$ \\
\hline \begin{tabular}{|l|}
$\begin{array}{l}\text { Haemoglobin } \\
(\mathrm{g} / \mathrm{dl})\end{array}$ \\
\end{tabular} & $10.61 \pm 2.03$ & $9.27 \pm 1.88$ & $7.76 \pm 1.42$ & $7.86 \pm 1.14$ & $<0.05$ \\
\hline \begin{tabular}{|l|}
$\begin{array}{l}\text { Blood urea } \\
(\mathrm{mg} / \mathrm{dl})\end{array}$ \\
\end{tabular} & $84.3 \pm 31.05$ & $114.52 \pm 39.08$ & $153.38 \pm 50.06$ & $208.8 \pm 85.84$ & $<0.001$ \\
\hline \begin{tabular}{|l|}
$\begin{array}{l}\text { Blood sugar } \\
(\mathrm{mg} / \mathrm{dl})\end{array}$ \\
\end{tabular} & $106.32 \pm 42.12$ & $114.62 \pm 42.62$ & $110.42 \pm 34.10$ & $111.74 \pm 35.93$ & $>0.05$ \\
\hline $\begin{array}{l}\begin{array}{l}\text { Serum creatinine } \\
(\mathrm{mg} / \mathrm{dl})\end{array} \\
\end{array}$ & $2.13 \pm 0.62$ & $2.97 \pm 0.73$ & $6.36 \pm 1.81$ & $9.92 \pm 2.94$ & $<0.001$ \\
\hline \begin{tabular}{|l|}
$\begin{array}{l}\text { Serum uric acid } \\
(\mathrm{mg} / \mathrm{dl})\end{array}$ \\
\end{tabular} & $6.62 \pm 1.90$ & $7.28 \pm 2.71$ & $7.93 \pm 2.53$ & $8.10 \pm 2.61$ & $>0.05$ \\
\hline \begin{tabular}{|l|}
$\begin{array}{l}\text { Serum potassium } \\
(\mathrm{meq} / \mathrm{l})\end{array}$ \\
\end{tabular} & $4.33 \pm 0.60$ & $4.43 \pm 0.58$ & $4.31 \pm 0.62$ & $4.18 \pm 0.60$ & $>0.05$ \\
\hline \begin{tabular}{|l|}
$\begin{array}{l}\text { Serum calcium } \\
(\mathrm{mg} / \mathrm{dl})\end{array}$ \\
\end{tabular} & $9.34 \pm 0.84$ & $8.69 \pm 0.87$ & $7.97 \pm 1.19$ & $7.51 \pm 1.30$ & $<0.05$ \\
\hline \begin{tabular}{|l|}
$\begin{array}{l}\text { Serum phosphate } \\
(\mathrm{mg} / \mathrm{dl})\end{array}$ \\
\end{tabular} & $4.31 \pm 1.06$ & $5.07 \pm 1.84$ & $6.40 \pm 2.27$ & $7.50 \pm 2.51$ & $<0.001$ \\
\hline \begin{tabular}{|l|} 
eGFR \\
$\left(\mathrm{ml} / \mathrm{min} / 1.73 \mathrm{~m}^{2}\right)$
\end{tabular} & $43.45 \pm 8.69$ & $22.57 \pm 4.15$ & $10.75 \pm 3.22$ & $7.88 \pm 2.86$ & $<0.001$ \\
\hline
\end{tabular}

*BMI - Body Mass Index, SBP-Systolic Blood Pressure, DBP- Diastolic Blood Pressure, MAP- Mean Arterial Pressure

**Analyzed by ANOVA

Table 2: Anxiety, Depression and Insomnia scores in each group

\begin{tabular}{|c|c|c|c|c|c|}
\hline & $\begin{array}{c}\text { Group A } \\
(\mathrm{n}=\mathbf{5 0})\end{array}$ & $\begin{array}{c}\text { Group B } \\
(\mathrm{n}=50)\end{array}$ & $\begin{array}{c}\text { Group C } \\
(\mathrm{n}=\mathbf{5 0})\end{array}$ & $\begin{array}{c}\text { Group D } \\
(\mathrm{n}=\mathbf{5 0})\end{array}$ & p value \\
\hline \begin{tabular}{|l|}
$\begin{array}{l}\text { Anxiety(HADS) } \\
(\text { Mean } \pm \text { SD) }\end{array}$ \\
\end{tabular} & $7.9 \pm 3.54$ & $10.46 \pm 3.05$ & $12.48 \pm 3.54$ & $13.82 \pm 2.73$ & $<0.001$ \\
\hline \begin{tabular}{|l|}
$\begin{array}{l}\text { Depression(HADS) } \\
(\text { Mean } \pm \text { SD })\end{array}$ \\
\end{tabular} & $7.24 \pm 2.62$ & $11 \pm 3.05$ & $12.16 \pm 3.36$ & $12.58 \pm 3.12$ & $<0.001$ \\
\hline \begin{tabular}{|l|}
$\begin{array}{l}\text { Insomnia(PSQI) } \\
(\text { Mean } \pm \text { SD) }\end{array}$ \\
\end{tabular} & $5.32 \pm 2.36$ & $7.54 \pm 2.57$ & $8.94 \pm 2.74$ & $9.94 \pm 3.76$ & $<0.001$ \\
\hline
\end{tabular}

*Analyzed by ANOVA

to be positively correlated to serum potassium levels while anxiety did not show any correlation to serum potassium. Anxiety and depression were also found to be negatively correlated with BMI however PSQI score did not had any significant correlation with BMI. Correlation of other variables such as age, MAP, serum uric acid, serum sodium, blood sugar with anxiety, depression and PSQI scores was also assessed in the study. However, the results were not statistically significant. Also anxiety, depression and insomnia were found to have a significant positive correlation to each other when Pearson correlation coefficient was used $(p<0.05)$.

\section{DISCUSSION}

Populations having chronic illness have been reported to have poorer quality of life and mental health, including higher levels of depression [8,9] In literature majority of studies have found that patients tends to experience depression or anxiety as a consequence of being diagnosed with a chronic disease $[10,11]$ Diagnosis of a chronic disease along with chronic and multiple drug therapy and frequent hospitalizations can contribute to depression or anxiety. Even though there has been increased attention on mental health in recent years, social stigma and 
Table 3: Categorized correlates and Anxiety, Depression and Insomnia Scores

\begin{tabular}{|c|c|c|c|c|c|c|c|}
\hline & & Anxiety Score & p value & $\begin{array}{c}\text { Depression } \\
\text { Score }\end{array}$ & p value & Sleep Quality & p value \\
\hline \multirow{2}{*}{$\begin{array}{l}\text { AGE } \\
\text { (years) }\end{array}$} & $<55$ & $11.21 \pm 4.02$ & \multirow{2}{*}{$>0.05$} & $10.60 \pm 3.85$ & \multirow{2}{*}{$>0.05$} & $7.77 \pm 3.45$ & \multirow{2}{*}{$>0.05$} \\
\hline & $\geq 55$ & $11.11 \pm 3.78$ & & $10.92 \pm 3.49$ & & $8.13 \pm 3.26$ & \\
\hline \multirow{2}{*}{ GENDER } & $\mathrm{M}$ & $10.92 \pm 3.81$ & \multirow{2}{*}{$>0.05$} & $10.64 \pm 3.58$ & \multirow{2}{*}{$>0.05$} & $7.98 \pm 3.54$ & \multirow{2}{*}{$>0.05$} \\
\hline & $\mathrm{F}$ & $11.60 \pm 4.07$ & & $10.93 \pm 3.89$ & & $7.86 \pm 3.06$ & \\
\hline \multirow{2}{*}{$\begin{array}{l}\text { BMI } \\
\left(\mathrm{kg} / \mathrm{m}^{2}\right)\end{array}$} & $\geq 22.5$ & $11.02 \pm 3.75$ & \multirow{2}{*}{$>0.05$} & $10.54 \pm 3.61$ & \multirow{2}{*}{$>0.05$} & $8.04 \pm 3.49$ & \multirow{2}{*}{$>0.05$} \\
\hline & $<22.5$ & $11.29 \pm 4.05$ & & $10.93 \pm 3.76$ & & $7.84 \pm 3.27$ & \\
\hline \multirow{2}{*}{$\begin{array}{l}\mathrm{HB} \\
(\mathrm{g} / \mathrm{dl})\end{array}$} & $\geq 9$ & $9.80 \pm 3.94$ & \multirow{2}{*}{$<0.001$} & $9.57 \pm 3.65$ & \multirow{2}{*}{$<0.001$} & $6.84 \pm 3.25$ & \multirow{2}{*}{$<0.001$} \\
\hline & $<9$ & $12.00 \pm 3.66$ & & $11.47 \pm 3.54$ & & $8.60 \pm 3.28$ & \\
\hline \multirow{2}{*}{ EMPLOYMENT } & Yes & $9.41 \pm 3.44$ & \multirow{2}{*}{$<0.001$} & $9.23 \pm 3.41$ & \multirow{2}{*}{$<0.001$} & $6.81 \pm 3.16$ & \multirow{2}{*}{$<0.001$} \\
\hline & No & $12.49 \pm 3.73$ & & $11.89 \pm 3.49$ & & $8.78 \pm 3.28$ & \\
\hline \multirow{2}{*}{ MARRIED } & Yes & $11.17 \pm 3.93$ & \multirow{2}{*}{$>0.05$} & $10.89 \pm 3.67$ & \multirow{2}{*}{$<0.05$} & $8.01 \pm 3.35$ & \multirow{2}{*}{$>0.05$} \\
\hline & No & $11.00 \pm 3.79$ & & $8.27 \pm 3.19$ & & $6.73 \pm 3.63$ & \\
\hline \multirow{2}{*}{ RESIDENCE } & Rural & $9.49 \pm 3.74$ & \multirow{2}{*}{$<0.001$} & $9.64 \pm 3.65$ & \multirow{2}{*}{$<0.001$} & $7.04 \pm 2.93$ & \multirow{2}{*}{$<0.001$} \\
\hline & Urban & $13.02 \pm 3.20$ & & $11.97 \pm 3.35$ & & $8.93 \pm 3.55$ & \\
\hline \multirow{2}{*}{ INCOME } & Low & $12.63 \pm 3.54$ & \multirow{2}{*}{$<0.001$} & $12.05 \pm 3.40$ & \multirow{2}{*}{$<0.001$} & $8.93 \pm 3.27$ & \multirow{2}{*}{$<0.001$} \\
\hline & High & $9.30 \pm 3.56$ & & $9.08 \pm 3.37$ & & $6.67 \pm 3.07$ & \\
\hline \multirow{2}{*}{ CO-MORBIDITY } & Yes & $13.53 \pm 2.91$ & \multirow{2}{*}{$<0.001$} & $13.08 \pm 2.51$ & \multirow{2}{*}{$<0.001$} & $9.65 \pm 3.22$ & \multirow{2}{*}{$<0.001$} \\
\hline & No & $8.75 \pm 3.28$ & & $8.36 \pm 3.14$ & & $6.18 \pm 2.51$ & \\
\hline
\end{tabular}

*Analyzed by Independent t-test.

Table 4: Correlation between Education and Anxiety, Depression and Insomnia scores

\begin{tabular}{|c|c|c|c|c|c|}
\hline & Elementary (a) & Secondary (b) & University (c) & \multicolumn{2}{|c|}{ p value* } \\
\hline \multirow{3}{*}{$\begin{array}{l}\text { Anxiety score } \\
(\text { Mean } \pm \text { SD) }\end{array}$} & \multirow{3}{*}{$11.58 \pm 3.91$} & \multirow{3}{*}{$10.72 \pm 3.87$} & \multirow{3}{*}{$10.0 \pm 3.90$} & a vs b & $>0.05$ \\
\hline & & & & $\mathrm{b}$ vs c & $>0.05$ \\
\hline & & & & $\mathrm{c}$ vs a & $>0.05$ \\
\hline \multirow{3}{*}{$\begin{array}{l}\text { Depression score } \\
(\text { Mean } \pm \text { SD) }\end{array}$} & \multirow{3}{*}{$11.51 \pm 3.48$} & \multirow{3}{*}{$9.53 \pm 3.79$} & \multirow{3}{*}{$10.40 \pm 3.48$} & a vs b & $<0.001$ \\
\hline & & & & $\mathrm{b}$ vs c & $>0.05$ \\
\hline & & & & $\mathrm{c}$ vs a & $>0.05$ \\
\hline \multirow{3}{*}{$\begin{array}{l}\text { Insomnia score } \\
(\text { Mean } \pm \text { SD) }\end{array}$} & \multirow{3}{*}{$8.62 \pm 3.38$} & \multirow{3}{*}{$6.73 \pm 2.95$} & \multirow{3}{*}{$8.13 \pm 3.73$} & $a$ vs $b$ & $<0.001$ \\
\hline & & & & b vs c & $>0.05$ \\
\hline & & & & $\mathrm{c}$ vs a & $>0.05$ \\
\hline
\end{tabular}

discrimination associated with mental illnesses remains a significant barrier to an individual's health and employment. The objective behind planning this study was to assess relationship between renal function, anxiety, depression and sleep quality and its predictors since there is scarcity of such studies in patients of CKD in Indian population and hence contribute in better management of these health issues in CKD patients.

The prevalence of anxiety and depression was found using the HADS score. Overall, Mykletun et al found that the HADS scale possessed good "psychometric properties in terms of factor structure, inter-correlation, homogeneity and internal consistency".[12] In another review conducted by Bjelland et al HADS was found to perform well in assessing the symptom severity of anxiety disorders and depression in both somatic, psychiatric and primary care patients and in the general population.[13] Sleep quality was assessed using PSQI score. Various studies have shown that the PSQI is an effective instrument used to measure the quality and patterns of sleep in the older adults.

Our results revealed a high prevalence of anxiety, depression and insomnia in CKD patients. A total of $142(71 \%)$ patients had anxiety (HADS-A >7), 138 (69\%) patients had depression (HADS-D $>7)$ and $173(86.5 \%)$ patients had poor sleep quality (PSQI $\geq 5$ ). The higher percentages for all three parameters were seen as compared to previous studies such as those done by Kutner et al who found the prevalence rate of depression and anx- 
iety to be $26.6 \%$ and $45 \%$ respectively and Cukor et al who found the prevalence rate of depression and anxiety to be $29 \%$ and $45.7 \%$ respectively in ESRD patients. ${ }^{14,15}$ These findings can be attributed to the facts that in the Indian population most of the people have low income status with poor approach to a good medical facility. Also a low level of education, financial issues, frequent visits for dialysis and prolonged waiting time aggravate the stressful conditions in CKD patients. In the study population $10 \%$ had mild, $36.5 \%$ had moderate and $24.5 \%$ had severe anxiety. The proportions of mild, moderate and severe depression were $11 \%, 43.5 \%$ and $14.5 \%$ respectively in the study population. The findings of our study also revealed that more advanced the stage of CKD greater is the prevalence as well as severity of anxiety, depression and insomnia. This implies that as CKD stage advances the mental health and sleep quality of patients get worse. Similar association of depressive symptoms with stage of CKD was seen by Palmer et al and Chiang et al in their respective studies.[16, 17] There is paucity of studies comparing anxiety in different stages of CKD. In another study conducted by Cantekin et al on pre dialysis patients it was found that $35 \%$ of patients had depression and $53.4 \%$ had anxiety. This study shows the presence of psychopathological problems before patients are started on dialysis.[18]

Sleep disorders are among the factors that can reduce the quality of life in patients with CKD. The prevalence of sleep disorders among CKD patients has been estimated to be around $41 \%$ to $83 \%$ by questionnaire-based studies, the most frequent complaints being difficulty in falling asleep, difficulty in maintaining sleep, daytime sleepiness, and fatigue.[19] Similar findings were observed in our study with $86.5 \%$ of patients having poor sleep quality based on PSQI questionnaire. Maqbool et al conducted a study on insomnia in patients of CKD which showed that insomnia is still a major problem in these subjects, since $42.9 \%$ of patients complained of this sleep disorder.[20] In another study conducted by Iliescu et al quality of sleep in patients with chronic kidney disease was measured using the Pittsburgh Sleep Quality Index (PSQI). 53\% patients had 'poor sleep' defined as a global PSQI score $\geq 5$.[21]

The effect of laboratory and socio-demographic parameters were also studied to evaluate their role in mental health and sleep quality. Patients in our study with hemoglobin $<9.0 \mathrm{~g} / \mathrm{dl}$, unemployed, those living in urban area and belonging to low income group had significantly higher scores and prevalence of anxiety, depression and insomnia $(p<0.001)$. These findings are in agreement with the study done by Tanvir et al which found a higher anxiety and depression score in patients with low socio-economic status and less education.[22] Sesso et al also found increased occurrence of depression in unemployed and low income patients.[23] Theofilou studied the effects of socio-demographic characteristics on anxiety and depression in patients of CKD and found a higher level of depression in low socio-economic group providing direct evidence that these patients face increased problems in their psychological well-being, social relationships and general health.[24] When compared, patients with co-morbidities had significantly higher scores than those with no co-morbidities $(p<0.001)$. Similar relation of depression with co-morbid diseases was seen by Patel et al. Depressed patients had greater levels of fatigue and anxiety, more common suicidal ideation, and poorer quality of life than non-depressed patients.[25] A relation between low income and presence of co-morbid illness with depression was also observed by Andrade et al in the study they conducted on CKD patients.[25] There is paucity of data comparing sleep quality with socio-demographic variables however in our study sleep quality was found to be significantly affected by employment status, income group, education level, residential area and association of a co-morbidity. Further studies are still warranted to clarify a relationship among them.

In our study no difference in anxiety, depression and insomnia scores was seen on the basis of BMI, age and gender. These findings are in contrary to those seen by Patel et al who found a direct relation of depression with low BMI.[25] However, these findings are in agreement to those seen by Chiang et al who studied the correlates of depression in CKD patients and found no relation of depression with age and gender.[17] In another study Theofilou found a direct correlation of depression with older age in indicating lower levels of physical well-being and higher levels of depression. [24] These difference might be due to different population structure and less number of elderly people in the population. Marital status also did not have any effect on anxiety and insomnia score although a significant higher value was found in married patients for the depression score. Similar results were seen by Tanvir et al who found higher score of depression in married patients.[22] Married people bear extra responsibility of their family. This along with enhanced 
financial burden and day to day expenses might aggravate depression in married people.

The effect of education was evaluated after dividing the study population in three groups on the basis of education level i.e. elementary (up to 8th), secondary (9-12th) and university (graduates). In overall, patients with lower socioeconomic profiles or lacking in education, which is generally taken as an indicator of social status, are reported in the literature facing problems in their psychological well-being, social relationships, and general health.[27] In our study also the less educated patients evaluated their health in a more negative way and reported higher prevalence and severity of anxiety, depression and insomnia.

The correlation of anxiety, depression and insomnia with various laboratory parameters was calculated using Pearson correlation. A significant negative correlation was seen between factors such as eGFR, serum calcium and decreased hemoglobin levels with anxiety, depression and insomnia scores. This means that patient's mental health perception is not only related to the renal function, but also to other conditions - like anemia commonly seen in patients of CKD. A significant positive correlation of these scores was seen with blood urea, serum creatinine, serum phosphate and TLC.

Sleep quality has been found to be related directly to anxiety and depression. To study the same a correlation was calculated, using Pearson correlation, between HADS-A, HADS-D and PSQI scores. A significant positive correlation was seen between all the scores. Similar results were seen by Chiang et al who examined the prevalence of depression, as well as the influence of other psychosocial factors on depression in Taiwanese CKD patients. The study revealed that those with sleep disorders are three times more likely to have depression than those who have good sleep.[17] Psychopathological states can be assumed to affect descending corticothalamic activity and thus both the initiation and maintenance of sleep by impairing the thalamic dampening of sensory information that characterizes sleep.[28] From a neurobiological perspective, the arousal system of individuals who experience insomnia was more active than in those of the general population. This phenomenon would cause altered corticothalamic activities, such as higher concentrations of adrenocorticotropin (ACTH) and cortisol, which might further predispose them to develop psychiatric disorders.[29, 30] In another study conducted by Iliescu et al a history of depression was found to be an independent predictor of 'poor sleep'.[21]

The results of this study should be interpreted with this limitation in mind that due to economic constraints, unwillingness of patients and various technical reasons the adequacy of dialysis could not be maintained in all patients of group D.

\section{CONCLUSION:}

Considering the worldwide growing prevalence of CKD and increasing importance of mental health in chronic diseases, improving our knowledge about psychiatric disturbances and its predictors in CKD patients is important. The deterioration of mental health in CKD is a complex multi-factorial problem which commences early and progress with the stage of disease. Therefore there is a need to develop strategies to accurately identify "high risk" subjects who may benefit from preventive measures before a complication begins to occur which will help in providing active and healthy life in CKD patients. In light of the weight of evidence for increased morbidity and mortality associated with depression and anxiety in $\mathrm{CKD}$, it becomes apparent that the research task of finding effective solutions is lagging a long way behind. Potentially useful targets for research include examining the effectiveness and safety of antidepressant and antianxiety medications, and the effectiveness of psychological and behavioral interventions. The "management" of depression and anxiety is complicated, as is the "management" of chronic illness. Because of the interaction of these two components, solutions will need to be integrated. It is therefore timely to develop and test the clinical and cost-effectiveness of integrated disease management systems for these psychiatric conditions in CKD. At present, health care is linear, we treat the physical disease first, and then refer the patient for mental health care, or vice versa. ${ }^{31}$ This is not effective, efficient or cost-effective. Models of integrated care need to be implemented and evaluated. Based on the principles of chronic disease management and the findings of this review, an integrated disease management system could include screening and monitoring, good disease information and self-management advice, as well as a range of cognitive and behavioral strategies applied in a stepped or tiered model. 


\section{REFERENCES}

1. Ginieri-Coccossis M, Theofilou P, Synodinou C, Tomaras V, Soldatos C. Quality of life, mental health and health beliefs in haemodialysis and peritoneal dialysis patients: investigating differences in early and later years of current treatment. BMC Nephrol 2008;9:14.

2. Aggarwal H K, Jain D, Pawar S, Yadav R K. Health-related quality of life in different stages of chronic kidney disease QJM: 2016, 1-6 (Ahead of print) doi: 10.1093/qjmed/hcw054.

3. Rai M, Rustagi T, Rustagi S, Kohli R. Depression, insomnia and sleep apnea in patients on hemodialysis. Indian J Nephrol 2011;21(4):223-9.

4. Coyne JC, Fechner BS, Schwenk TL. Prevalence, nature, and co-morbidity of depressive disorders in primary care. Gen Hosp Psychiatry 1994;16:267-76.

5. Williams SW, Tell GS, Zheng B, Shumaker S, Rocco MV, Sevick MA. Correlates of sleep behavior among hemodialysis patients. Am J Nephrol 2002;22:18-28.

6. Holley JL, Nespor S, Rault R. A comparison of reported sleep disorders in patients on chronic hemodialysis and continuous peritoneal dialysis. Am J Kidney Dis 1992;19:156-61.

7. Buysse DJ, Reynolds CF, Monk TH, Berman SR, Kupfer DJ. The Pittsburgh sleep quality index: a new instrument for psychiatric practice and research. Psychaitric Research 1989;28(2):193-213.

8. Nilsson J, Rana AKMM, and Kabir ZN. Social capital and quality of life in old age: results from a cross-sectional study in rural Bangladesh. Journal of Aging and Health 2006;18(3):419-34.

9. Borglin G, Jakobsson U, Edberg AK, Hallberg IR. Older people in Sweden with various degrees of present quality of life: their health, social support, everyday activities and sense of coherence. Health and Social Care in theCommunity 2006;14(2):136-46.

10. White JH, Magin P, Attia J, Pollack MR, Sturm J, Levi CR et al. Exploring poststroke mood changes in community-dwelling stroke survivors: a qualitative study. Arch Phys Med Rehabil 2008;89:1701-7.

11. Ahlström G. Experiences of loss and chronic sorrow in persons with severe chronic illness. J ClinNurs 2007;16(3A):76-83.
12. Mykletun A, Stordal E, Dahl A. Hospital anxiety and depression scale: factor structure, item analyses, and internal consistency in a large population. Brit J Psychiat 2001;179: 540-4.

13. Bjelland I, Dahl AA, Haug TT, Neckelmann D: The validity of the Hospital Anxiety and Depression Scale. An updated literature review. J Psychosom Res 2002;52:69-77.

14. Kutner NG, Fair PL, Kutner MH. Assessing depression and anxiety in chronic dialysis patients. J Psychosom Res 1985;29:23-31.

15. Cukor D, Coplan J, Brown C. Anxiety disorders in adults treated by hemodialysis: a single-center study. Am J Kidney Dis. 2008;52:128-36.

16. Palmer S, Vecchio M, Jonathan C, Craig, Tonelli M, Nicolucci A et al. Prevalence of depression in chronic kidney disease: systematic review and meta-analysis of observational studies. Kidney Int 2013;84:179-91.

17. Chiang H, Livneh H, Yen ML, Li TC, Tsai TY. Prevalence and correlates of depression among chronic kidney disease patients in Taiwan. BMC nephrol 2013;14:78.

18. Cantekin I, Curcani M, Tan M. Determining the anxiety and depression levels of pre-dialysis patients in eastern Turkey. Ren Fail 2014;36(5):678-81.

19. Lucidi F, Violani C, De Santo RM, Devoto A, Lombardo C. Insomnia is associated with systolic hypertension in uremic patients on hemodialysis. Int J Artif Organs 2001;24:853-62.

20. Khan M, Ahmad M, Mir S. Insomnia in Patients of Chronic Renal Failure on Hemodialysis. Ann Pak Inst Med Sci 2011;7:165-8.

21. Iliescu EA, Yeates KE, Holland DC. Quality of sleep in patients with chronic kidney disease. Nephrol Dial Transplant 2004;19:95-9.

22. Tanvir S, Butt G, Taj R.Prevalence of Depression and Anxiety in Chronic Kidney Disease Patients on Haemodialysis. Ann Pak Inst Med Sci 2013;9(2):64-7.

23. Sesso R, Rodrigues-Neto JF, Ferraz MB. Impact of socioeconomic status on the quality of life of ESRD patients. American Journal of Kidney Diseases 2003;41(1):186-95.

24. Theofilou P. Depression and Anxiety in patients with chronic renal failure: the effect of sociodemographic characteristics. Int J of Nephrol 2011:514070 
25. Patel ML, Sachan R, Nischal N, Surendra. Anxiety and Depression-A Suicidal Risk in Patients with Chronic Renal Failure on Maintenance Hemodialysis. Int J sci and res pub 2012;2:2250-3158.

26. Andrade CP, Sesso RC. Depression in Chronic Kidney Disease and Hemodialysis Patients Psychology. Sci Res 2012;3:974-8.

27. Rebollo P, Ortega F, Baltar JM, Diaz-Corte C, Navascues RA, Naves M et al. Health-related quality of life (HRQOL) in end stage renal disease (ESRD) patients over 65 years. Geriatric Nephrology and Urology 1998;8(2):85-94.

28. Steriade M, McCormick DA, Sejnowski TJ. Thalamocortical oscillations in the sleeping and aroused brain. Science 1993;262:679-85.
29. Neckelmann D, Mykletun A, Dahl AA. Chronic insomnia as a risk factor for developing anxiety and depression. Sleep 2007;30:873-80.

30. Baglioni C, Battagliese G, Feige B, Spiegelhalder K, Nissen C, Voderholzer U et al. Insomnia as a predictor of depression: a metaanalytic evaluation of longitudinal epidemiological studies. J Affect Disord 2011;135:10-19.

31. Kathol RG, Clarke DM. Rethinking the place of the Psyche in health: toward the integration of health care system. Aust N Z J Psychiatry 2005;39:816-25.

\title{
ПРЕВАЛЕНЦИЈАТА НА ДЕПРЕСИЈАТА, АНКСИОЗНОСТА И НЕСОНИЦАТА КАЈ ПАЦИЕНТИТЕ СО ХРОНИЧНА БУБРЕЖНА БОЛЕСТ И НИВНАТА КОРЕЛАЦИЈА СО ДЕМОГРАФСКИТЕ ПРОМЕНЛИВИ
}

\author{
Х.К. Агарва, Дипак Јаин, Гета Дабас, Р К Јадав \\ Оддел за медицина и Одделение за нефрологија \\ Пт. Б.Д. Универзитет Шарма за здравствени науки, РОХТАК-124001 (Харјана) Индија

\section{Резиме}

Историја: Хроничната бубрежна болест (ХББ) е растечки здравствен проблем во развиените и во земјите во развој. Депресијата, анксиозноста и нарушувањата на спиењето се многу распространети кај пациентите со хронична болест, но остануваат нетретирани и покрај значителните негативни последици врз здравјето на пациентите. Проценката на клучните компоненти на менталното здравје рано во текот на болеста ќе помогнат за да се идентификуваат субјектите со висок ризик кај кои модифицирањето на овие показатели ќе помогне во обезбедување на активен и здрав живот кај пациентите со ХББ.

Методи: Направивме студија со 200 пациенти со ХББ, стадиум III до V-D што ги исполнуваат критериумите за подобност и кои беа следени во еден терциерен центар за заштита во државата Харајана, Индија. Ние ја оценувавме распространетоста на анксиозноста, депресијата и несоницата и нивната корелација со демографските варијабли кај овие пациенти. Структурираниот прашалник користен во оваа студија собираше информации за демографските карактеристики и карактеристиките за болестите на испитаникот, како и информациите добиени од прашалникот HADS и PSQI. Факторите поврзани со анксиозност, депресија и несоница беа испитани со анализа на повеќекратна логистичка регресија.

Резултати: Преваленцијата на анксиозноста, депресијата и несоницата беше 71\%, 69\% и 86,5\%, соодветно. Како што фазата на ХББ напредуваше, распространетоста и тежината на овие параметри се зголемуваше. Утврдено е дека анксиозноста, депресија и квалитетот на сонот се значително во корелација со невработеноста, ниските приходи, ниското образование, урбаното живеење и присуството на коморбидитети. Утврдено е дека резултатите на анксиозноста, депресијата и несоницата 
имаат силна негативна корелација со eGFR, хемоглобинот, серумски калциумот ( $<0.01)$ и позитивна корелација со TLC, уреата во крвта, серумскиот креатинин и серумскиот фосфат $(\mathrm{p}<0.05)$.

Заклучок: Ние ја следевме високата преваленција на анксиозноста, депресијата и несоницата кај пациентите со ХББ. Постои потреба да се развијат стратегии за точно да се идентификуваат субјектите со „висок ризик“ што може да имаат корист од превентивните мерки пред да се појават компликациите. Со идентификувањето на пациенти со ХББ со висок ризик за овие ментални здравствени работи, здравствената институција може подобро да обезбеди давање на соодветна рехабилитација на оваа популација.

Клучни зборови: хронична бубрежна болест, депресија, анксиозност, несоница. 